Vol. 11 (3): 515-520 (2021)

\title{
TECHNICAL AND MANAGEMENT ASPECT OF WOOD INDUSTRY RELATED TO THE TRAINING OF ENGINEERS WHO ARE PART OF THIS SECTOR
}

\author{
Ramadan Topuzi ${ }^{*}$, Lulzim Idrizi ${ }^{1}$, Bujar Jashari ${ }^{1}$, Agron Bajraktari $^{1}$ \\ ${ }^{1 *}$ University of Applied Sciences in Ferizaj, Kosovo; \\ *Corresponding Author Ramadan Topuzi, e-mail: ramadan.topuzi@ushaf.net;
}

Received March 2021; Accepted May 2021; Published June 2021;

DOI: https://doi.org/10.31407/ijees11.322

\begin{abstract}
Technical aspects in the wood processing entities is closely related to the recognition and application of the new technology. Another very important aspect of these businesses is management. They are employed in these businesses Wood Processing engineers who graduate in the Department of Wood Industry of the Agricultural University of Tirana. In this institution, students, in addition to general knowledge, science and engineering, acquire knowledge of technology and management. This study analyzes the technical and managerial problems of wood industry in Albania; relating to the knowledge of Woodworking engineers. Generally, the faculty is satisfied with the knowledge it gives to the student during the teaching process, internships, until his graduation. After graduation, it is the private sector that practically employs engineers, but it is also an indicator of measuring the degree of their formation. University education of students is very important and is seen by the labor market as a potential for continuous development and progress. The study is based on the analysis of a significant number of questionnaires structured for this purpose. The study shows that newly graduated engineers do not have the proper knowledge of new technologies. Also it needs to be done in terms of their formation with knowledge about management, especially in the conditions of Albania. The surveyed engineers say that they also need to play the role of the manager.
\end{abstract}

Key words: wood industry, wood processing engineers. 